\title{
The Industrial Development Strategy of Krasnoyarsk Krai: Challenges and Actors of Development
}

\author{
Zoia A. Vasileva, Tatiana P. Likhacheva \\ and Svetlana B. Globa* \\ Siberian Federal University \\ 79 Svobodny, Krasnoyarsk, 660041, Russia
}

Received 17.05.2016, received in revised form 22.08.2016, accepted 19.09.2016

The article analyzes the industrial policy implemented in Russia in the course of the last decade. It discusses the basic problems and prospects of the industrial policy implementation including the opportunity of large companies' activity localization. The features of the industrial development of Krasnoyarsk Krai are stated. The principles of the industrial policy that ensure the development of the industrial sector in Russia, Siberia and the Far East are set forth. The article also views the complex of problems connected with the formation of the region's industrial policy aimed at an innovative way of development and growth of high-tech sectors of the economy focused on new commodity markets. The types of industrial policy, its goals, objectives, characteristics and potential are stated. The proposals for the industrial policy of Krasnoyarsk Krai are developed.

Keywords: industrial production in Russia, industrial development, industrial policy, regional development, industrial policy of Krasnoyarsk Krai.

DOI: 10.17516/1997-1370-2016-9-11-2582-2591.

Research area: economics.

Industrial policy is an interdependent set of measures to support the industry development by means of regulatory instruments.

The need for the industrial policy improvement is caused by the challenges and threats coming from the outside world as well as problems in the development of Krasnoyarsk Krai.

The most significant challenges and threats are the following ones:

- current dynamic situation in the global industrial sector (a new wave of technological changes and fundamental changes in commodity and production structures resulting from new materials and production organization on the basis of modern information technologies);

- changes in the industrial development priorities: from technologies of production to technologies of materials; from production management to product life cycle management;

- formation of new forms of production organization within cluster structures, global technology chains: from competitive business

(c) Siberian Federal University. All rights reserved

* Corresponding author E-mail address: globasb@yandex.ru 
models to cooperation models; from vertically integrated structures to horizontal structures of arbitrary configuration;

- sharp changes in the world raw materials market prices, impeding assessment of the prospects for economic development of extractive industries and their investment attractiveness;

- acute shortage of financial resources, aggravated by the global financial crisis and introduction of sanctions.

The problems of the industrial development of the krai include:

- closure and production decline in a number of companies - (decay in business activities and systems in the period of the domestic market contraction), decrease in the production of products with high added value;

- reduction of the industrial capacity that can be involved in the projects of the development of the North and formation of transport infrastructure of Siberia and the Far East under the federal programs;

- the real sector's low susceptibility to innovations;

- low profitability in the manufacturing sector of the economy and, as a consequence, inability to modernize production at the expense of own means;

- unavailability of long-term, cheap loan funds for modernization of the existing enterprises and establishment of new ones;

- location of the decision-making centers of large corporations in Moscow that has a negative impact on the process of the formation of material and technical resources and services procurement.

Yet, the existing competitive advantages and opportunities of Krasnoyarsk Krai development make it possible to overcome negative trends under certain conditions and to join common economic and technological space of the Eurasian Union, to position itself towards the Eastern vector of the development.

The industrial policy of Krasnoyarsk Krai is a regional-sectoral aspect of state industrial policy, the policy being a complex of legal, economic and organizational measures aimed at the development of the industrial potential for the production of competitive products as adjusted for the peculiar features of the regional development and resource base.

The industrial policy of Krasnoyarsk Krai is based on the mechanisms of the coordinated interaction of public authorities, local government, business and academic community on issues of the innovative capacity formation and management of the industrial complex development on the basis of maximum use of the region's domestic resources, creation of the conditions to stimulate the region's investment activity and preferences for attracting the investors.

The goals of industrial policy are the following ones:

1. the formation of high-tech, competitive industry, providing the state economy transition from an export-raw type of development to an innovative one;

2. the krai's population employment and raising their standard of living.

The achievement of the industrial policy goals is based on the sequence of terms of implementation (medium term, long term prospects), structuring of the elements in compliance with the industrial policy (import substitution policy, export-oriented policy, and innovational development policy) and interrelationship of measures of support for the regional industrial complex development.

The objectives of industrial policy are the following ones:

1. Modern industrial infrastructure formation and development.

2. The industrial activity actors' encouragement for the implementation of the 
intellectual activity results and mastering the innovative industrial production;

3. The industrial activity actors' encouragement for a rational and efficient use of material, financial, labor and natural resources, betterperformance, import-substituting, resourcesaving and ecologically safe technologies implementation;

4. The increase of high added value products output and their export promotion;

5. Promotion of industrial activity actors' technological modernization, modernization of basic production assets as per the pace, advancing their aging.

Industrial policy is aimed at the integrated use of the basic elements of structural, investment and innovation policies in a socio-economic development of the krai, prioritization of the development, means of the industrial activity actors' support, and formation of the investment incentives for innovative activities.

Industrial policy is based on the principles declaredbythestateauthoritiesintheprogramming documents of the industrial development of Russia till 2030 and specific character of their realization in Krasnoyarsk Krai, the krai being an industrial area for implementation of large investment projects of federal significance.

The industrial policy of Krasnoyarsk Krai should be based on the following principles:

1. Priority of industrial development as the base of the regional economic sectors technological modernization and major socioeconomic challenges implementation.

2. Equilibrium of public interest, industrial activity actors' interests and interests of the regional territories' population while choosing strategic priorities and directions of development.

3. Validity of the criteria of the state support of the industrial activity actors and economic agents of commodity markets, preferences in the administrative resource allocation to support the products promotion on the interregional and global commodity markets.

4. Mutual benefit of cooperation terms for the industrial activity actors on the basis of raw materials, material and financial potentials of Krasnoyarsk Krai.

5. Coordination of the interaction of the Russian Federation state authorities, governmental authorities of the subjects of the Russian Federation and local self-government.

Industry is one of the leading sectors of the economy of Krasnoyarsk Krai. It significantly contributes to the gross regional product (about $50 \%$ ) and ensures the receipt of more than $70 \%$ of tax payments in the consolidated budget (The official site of Krasnoyarsk Statistical Service).

Currently, the following activities constitute a largest share in the structure of the industrial complex: fuel and energy minerals extraction - 26,3\%; metallurgic production and finished metal products production $-39,2 \%$; electricity, gas and water production and distribution - 11, $2 \%$ (Ibid.).

The main points of investment activity in the krai have not changed for many years, the points being oil and gas complex, power engineering, forest industry, non-ferrous metallurgy and transport industry. Processing of agricultural production has been actively developing.

Krasnoyarsk Krai, located in the heart of the Eurasian continent, is a major transit hub at the intersection of the Trans-Siberian railway and historically formed trade routes along the Yenisei. It has an outlet to the seas of the Arctic Ocean. All types of transport systems cross the territory. These are the "Transsib" international railway corridor, the "Yenisei - Northern Sea Route" interoceanic transport corridor, air transpolar routes across the North Pole connecting North America and the countries of Southeast Asia. Nevertheless, insufficient development of 
transport infrastructure and complicated transport accessibility of the Northern regions are peculiar for the krai. These are due to a considerable geographical extent of the territories of the krai.

Manufacturing covers 14 economic activities, the metallurgical sector being the basis of the industrial potential of Krasnoyarsk Krai. The abundant reserves of nonferrous metal ores and an increasing demand for non-ferrous metals on the world market are main factors of its development. The main Russian stocks of platinum and platinum group metals as well as significant stocks of nickel, copper, cobalt, silver and rare earth metals are accumulated in the krai. The share of the metallurgical complex production is $48.8 \%$ (2.4 \% - metallurgical ores mining, $46,4 \%$ - metallurgical production). Mining and metallurgical enterprises provide more than $70 \%$ of the regional export (Ibid.).

The state of the energy complex largely determines the economic development of the krai. As per the results of 2014 the total installed capacity of the power plants in Krasnoyarsk Krai in 2014 is more than 16 GW (Ibid.). This ensures the krai's leading positions in the Russian Federation. The need for the development of the electric power industry in Krasnoyarsk Krai is determined by the needs of the metallurgical, oil and gas and timber industry complexes of Krasnoyarsk Krai.

The construction of the first stage of Boguchansk aluminum plant "Rusal UC" with the capacity of 150 thousand tons was one of key projects carried out in 2015. In general, a large industrial and energy hub has already developed in Boguchansky district. In 2015 the electricity output of the Boguchansk Hydroelectric Station increased, as compared with 2014, and exceeded 13 billion $\mathrm{kW} / \mathrm{h}$ (Ibid.). The third power unit of Berezovskaya regional power station (a member of "E. ON Russia" corporation) is the second significant object, put into operation in 2015. The installed capacity of the station will be $2.4 \mathrm{GW}$, thus making it the most powerful thermal power plant of the krai (the share of the regional power station output in the energy balance will exceed $20 \%$ ). As a result, the electricity production by hydroelectric and thermal power plants of the krai in 2015 turned out to be almost equal. The amount was more than 34 billion $\mathrm{kW} / \mathrm{h}$ in both cases. On the whole, the growth in this sector was $6.2 \%$ per year (Uklonov, 2016).

Despite a difficult situation in the economy, which is primarily due to the external economic factors (increase in the exchange rate, fall in oil and export metals prices), the situation in metallurgy and oil and gas industry, which are key export-oriented sectors of the krai economy, remained stable. Oil production at Vankor field did not decrease and was 22 million tons (the same as in 2014). Metallurgy also maintains the rates, and "Norilsk Nickel" mining-and-metallurgical integrated works keeps on modernization of the polar branch facility at that. The production of precious metals has increased, the increase being connected with the "Polus" company's projects. The performance in timber industry has improved. This year the tax liabilities of forest industry enterprises to the krai budget have increased by $15 \%$ (Ibid.).

However, as compared to 2014, the growth rate of the industrial production in the krai turned out to be negative for the year as a whole. Its index amounted to $98.9 \%$. It is the index of manufacturing $(97,9 \%)$ that reduced most strongly in almost all the segments except for wood processing and production of coke and oil products. Generally, the turnover of all enterprises of the krai has increased by $8.8 \%$ for the year and exceeded 2.7 billion rubles (The official site of Krasnoyarsk Statistical Service).

Manufacturing has a commanding lead and forms a pivotal potential of economic development. A significant share of fixed assets 
and investments in the fixed capital is concentrated in it (over $60 \%$ ). About $20 \%$ of the average number of employees is engaged in mining and processing productions as well as in electricity, gas and water production and distribution, their turnover constituting more than a half of that of all the organizations of the krai (Ibid.).

However, the industrial complex in Krasnoyarsk Krai has its own specifics. The industrial output in the krai is mainly focused on the industrial consumption as it is used as constituent parts for the production of capital or consumer goods.

The main factor of vulnerability and potential instability of the krai's economy is the dependency on export of resources at low efficiency and competitiveness of processing industries. Metals, wood, chemical and mineral products dominate in the structure of export, whereas machine-technical products dominate in the structure of import. Export exceeds import by five times.

This situation is negatively influenced by insufficiently favorable investment climate and inadequate institutional environment. It results in weak positions in the export of non-primary goods, significant import of finished products and capital outflow, and, consequently, the reduction of the opportunities for the economy modernization and development.

The competitive advantages of the industrial complex of Krasnoyarsk Krai are the following ones:

- powerful scientific and technical potential, unique productions and large specialized enterprises; background experience of international economic cooperation, availability of traditional sales markets (space industry, metallurgical industry);

- availability of land resources suitable for use as potential investment sites for new production facilities;
- a high degree of business activity, structures of business support and sectoral selfgovernment;

- availability of energy resources in the territorial plan;

- the developed scientific and educational complex;

- established foreign economic relations.

Along with this, the solution is needed for the problems, which are the most typical for the industrial complex. These problems are the following ones:

- a high level of physical and moral depreciation of fixed assets and shortage of funds for their modernization; high power-intensity of output products; ineffectiveness of the enterprise management system leading to their bankruptcy and closure;

- a low level of competitiveness of production of a number of the producers in the krai; strengthening of the positions of competitive import having a retarding effect on own production development; low level of the industrial enterprises' cooperation ties;

- a low level of innovative production output; insufficient initiation of changes in the economy structure to the knowledge economy, innovations; slow response to changing market requirements, insufficient level of production diversification, lack of efficient production clusters that would actively involve universities and research institutes as their integral components, lack of globally important research networks and global technology initiatives;

- orientation of the industry mainly towards old traditional markets. The sectors, which are estimated as new ones to the krai (new technological systems in metalworking), actually belong to mature traditional markets. They are not growth drivers in the next phase of national and global economy development. Thus, they will neither grow at a rate exceeding 
$10-15 \%$ per year nor be attractive investments to the capital;

- priority orientation of the krai industry towards the development of production rather than technology leads to the competition with other, more mobile and attractive sectors of economy. This causes strong pressure on the industrial sector of economy of Krasnoyarsk Krai, washes the investments, personnel, resources out of the industry, making them less available and more expensive;

- an insufficient level of cluster initiatives support prevents from significant agglomeration of productive forces. This is partly due to the total deficit of institutionally and legally issued intracluster up to date communication;

- lack of the formed "order for new economy" and new industry as a base of own development in the krai. The target programs of innovative economy development, which are significant at the global level, are not initiated by the largest actors in the industry. Accordingly, they are not implemented in the krai. Neither the strategies of the krai development on the basis of new technological platforms nor new large promising market segments are defined;

- lack of the intellectual property market, know-how of high level with the rights on them being the main object of sales abroad.

As for oil production enterprises, petroleum products production, metallurgical and chemical industries, favorable external situation and domestic demand growth are characteristic of them. Manufacturing, in its turn, demonstrates unsustainable development primarily in the engineering industry the products of which are inferior in their quality to the imported products in the course of competition for the domestic market, running along with a low growth of export. All of this creates a threat of resumption of a trend towards slower economic growth, organization of high-scale redistributions (primarily of agricultural products, machinery, and all types of processing of raw materials, including petroleum products).

Perspective trends of the industrial complex development in the krai are determined on the basis of the trends of development of global technologicalindustriesandinterrelationsbetween the global economy sectors, strategic directions of the national technology initiatives, available resource capacity of the regional industrial complex and the need for the formation of the innovative potential of the industrial complex as a basis for a sustainable socio-economic growth in terms of threats and challenges in the external environment.

Formation of a network of industrial clusters as instruments for resources mobilization for dynamic economic growth, competitiveness and diversification of the krai economy on the basis of the management mechanisms of the local industries (technology) interaction is a strategic priority direction of the development of the industrial complex of the krai, the clusters being growing points of creating a total innovation product of the krai with the involvement of publicprivate partnership.

The cluster approach acts as a tool of industrial policy, a new technology of managing the regional development creating business opportunities in the conditions of the transition to an innovative model of the krai economy due to:

- the formation of new professional competences of the cluster members (capacity for innovations through flexible forms of organization of production; efficient solution of target tasks of development by simplifying an access to new technologies and reducing transaction costs);

- the formation of new opportunities in the krai (development of priority foreign trade activities by small, medium and big business combination; growth of employment and contributions to the budgets of different levels 
due to the involvement of new economic activities and new members of the cluster; growth of labour productivity due to scale effects, agglomeration, increase of specialization and outsourcing of noncore industries);

- the formation of effective mechanisms of the interaction between government and business (reducing the need for public investments for priority foreign economic activities development; increasing the level of trust between cluster members in the issues of use of production, financial, and human capital, strengthening of independence and improving the status of the companies);

- the competitiveness of the krai through integration into global production chains; accelerating the promotion of technological initiatives in the krai through a cooperative search of ways while using the capabilities and tools at the federal level).

Creation of a biotechnology cluster is a priority direction, the cluster being a basis for the formation of a new industrial model of the industrial complex development in the krai in the form of a network of clusters. The clusters are based on the technologies of using living organisms and their components to produce new materials, environmentally friendly products by the enterprises of different profile and scale in mining, metallurgical, wood-chemical industries, energy, agro-industrial branch of production, medicine and healthcare, environmental management:

- biotechnologies for extractive industry (technologies using microorganisms for mining, coal, petroleum industries; technologies of bioextraction of useful elements of rare rocks);

- biotechnologies for metallurgical industry (bio-hydro-metallurgy is microbial leaching of metals from ores, manufacture of corrosionresistant bimetals; biochemicals for oil extraction and transportation);
- biotechnologies for power engineering (bio power engineering is power development from renewable raw materials of biological origin on an industrial scale (bio-fuels: biogas, fuel pellets, briquettes);

- biotechnologies for medicine and public health (technology for diagnostics of diseases, early diagnostics of hereditary diseases, regenerative therapy; bio-photonics);

- biotechnologies for wood-chemical industry and agroindustrial complex (technologies of using biomass as raw materials for the production of primary and secondary chemical components: biopolymers; lignocellulose for processing agricultural waste; microbiological agents of plant protection; extension of natural borders of the individual tree species cultivation);

- biotechnologies for environmental management, formation of the ecosystems of Siberia and transition to eco-economics (wastewater treatment; solid waste disposal; bioremediation of gas emissions; hazardous substances utilization and scavenging).

Breakthroughs in the field of materials technology and deep processing of metals for the production of new products and formation of new markets of oil and gas, metallurgical, timber and agricultural complexes of the krai are priority ones in the framework of the strategic trends, determined by the projections of technological changes and national technology initiatives of the Russian Federation:

- machine-building complex (technologies of composite materials; technologies of utilization and recycling of machine elements and structures of light alloys on terminating the life cycle, stockpiles and wastes of mining industry; mechanical systems of ensuring the biomedical technologies, tools and devices; technologies of production of mechanical systems of processing and production of the equipment for oil and gas complex, fuel and energy 
complex, timber industry, agro-industrial and metallurgical complexes);

- metallurgical complex (production of flat products for aviation and shipbuilding industries; technologies of corrosion-resistant covering production for automobile industry, a new class of fire-resistant structural steel for construction industry; biohydrometallurgy; biogeotechnologies; technologies of platinum group metals and gold processing for the production of medicinal substances and medicines);

- oil-and-gas and heat-and-power complexes (infrastructure development of related industries: coal chemistry, biochemistry, wood chemistry, agricultural chemistry; manufacture of petrochemical products: plastic, rubber, inorganic synthesis products).

The opportunities provided within the framework of the federal target programs, targeted innovation programmes within the national technological initiatives framework; the investment fund of the Russian Federation, the Fund of the regional development; the funds of the Bank for development and foreign economic activity; state budget funds allocated for the development of special economic zones, national projects, techno parks; venture capital funds; funds of the small business development programs, etc. can be used as sources of funding the clusters' activities.

Selection of priority directions of the industrial complex of Krasnoyarsk Krai development, a set of measures and mechanisms for the support of industries and activities development depend on the goals, objectives and stages of implementation determined by the peculiar features of the industrial policy types:

- import substitution policy;

- export-oriented policy;

- innovation development policy.

1. The import substitution policy is a governmental support of the recovery process of the internal elements of production chains based on the use of the resource potential of existing technologies and improvement of the traditional industries efficiency in the krai.

The goal of the import substitution policy is structural optimization of the material-andtechnological support of production processes and domestic consumption of the industrial complex products for the formation of competitive advantages and implementation of substitution mechanisms.

The objectives of the import substitution policy are:

1. to reduce the share of import in domestic consumption of the products of the industrial complex of the krai;

2. to form the institutional environment of business activities stimulation in the field of import substitution.

Implementation Stages - Stabilization Stage

The import substitution policy should be focused on the efficient use of the industrial potential of the krai and creation of basic framework for the export-oriented industrial development policy implementation.

The potential of the import substitution policy is middle technological production the products of which are imported to Krasnoyarsk Krai:

- mechanical engineering (machinery and mechanical devices; electrical machines and equipment; vehicles: motor cars, tools and devices);

- chemical industry (inorganic chemical products; organic chemical compounds, rubber and rubber products, plastics, composites);

The complex of measures of state support should be aimed at the development mechanisms of "triggering nature".

2. The export-oriented policy is a governmental support of the formation processes 
of previously missing productions providing for the integration of manufacturing industries of the krai into global production chains on the basis of investment prospects increase and new technological industries formation with the use of the international cooperation mechanisms.

The goal of the export-oriented policy is structural optimization of an international integration of the industrial complex for the formation of an export potential of the krai.

The objectives of the export-oriented policy are:

1. to increase the share of export products on the basis of technological modernization of processing industries and basic sectors of the economy of the krai;

2. to ensure the conditions for the production infrastructure formation for the missing industries of global production chains;

3. to form an institutional basis for the enterprises to enter international commodity markets with their new products with high added value.

Implementation Stages - Technological Modernization Stage

The potential of the export-oriented policy is high-tech manufacturing the products of which can be exported due to a high level of competitiveness:

- products of oil and gas refining of high purity, light low-sulphur grades of oil; petrochemical products (plastic, rubber, products of inorganic synthesis);

- metallurgical products (flat products for aviation and shipbuilding industries; corrosionresistant bimetals for automobile industry; a new class of fire-resistant structural steels).

\section{The innovation development policy} is a governmental support of the processes of formation of new high-tech sectors based on the knowledge economy enabling the transition to new business models of the production-and- spatial development and industrial complex management of the krai.

The goal of the innovation development policy is structural diversification of the industrial complex of the krai on the basis of innovative technologies in the field of production, high-technology services, and business management for the formation of the potential of innovative growth factors of the krai's strategic competitiveness.

The objectives of the innovation development policy are:

1. to ensure the growth of output of products with high added value;

2. to create the conditions for the innovative technology enterprises growth and high-tech jobs;

3. to form an institutional environment in order to create high-tech industries focused on new product markets.

Implementation Stages - the Stage of Innovative Breakthroughs

The potential of the innovation development policy is allocation of economic sectors as per their innovation priority:

- the sectors focused on priority development of scientific and technical potential ensuring global competitiveness (biotechnological cluster, information-and-telecommunication cluster, new materials);

- the sectors focused on technological modernization of priority sectors and separate breakthrough technologies (new motor fuels production, new generation of fuel cells, new electric power installations and efficient systems of $\mathrm{dc}$ transmission at a great distance; special equipment for work in the Arctic and extreme environments; new technologies of metal working; software and engineering services);

- the sectors focused on high-tech sectors (space-rocket, radio-electronic sectors, power engineering, ICT): 
space-rocket (the GLONASS system development: navigation spacecrafts of new generation, navigation equipment);

radio electronics (formation of infrastructure in system-oriented design centers, design centers, silicon factories, scientific and technological centres of micro-systems engineering); information and communication technologies - ICT (equal access to information technologies for all the residents of the krai; creation of a universal information and logistic operator on the basis of a postal operator for cargo transportation service between Europe and Asia; spatial data infrastructure development, distant and media education).

\title{
References
}

Efimov, V.S., Efimov, A.V., Vasileva, Z.A. (2015). Problemy promyshlennogo razvitiia Rossii i zadachi promyshlennoi politiki dlia Sibiri i Krasnoiarskogo kraia [Problems of Russia's Industrial Development and Objectives of Industrial Policy for Siberia and the Krasnoyarsk Territory], In Journal of Siberian Federal University. Series: Humanities \& Social Sciences, 8 (Supplement), 52-82.

Federal State Statistics Service. Central Statistical Database (2015), available at: http://www.gks. ru/dbscripts/cbsd/DBInet.cgi (accessed 5 February 2016).

The Official Site of Krasnoyarsk Statistical Service, available at: http://www.krasstat.gks.ru/

Vasileva, Z.A., Likhacheva, T.P., Filimonenko, I.V. (2015). Sistemnyi podkhod k promyshlennoi politike regiona [The System Approach to the Industrial Policy of the Region], In Ekonomika $i$ Predprinimatel'stvo [Economics and Entrepreneurship], 11-1 (64-1), 364-369.

\section{Стратегия промышленного развития Красноярского края:} задачи и субъекты развития

\author{
3.А. Васильева, Т.П. Лихачева, С.Б. Глоба \\ Сибирский федеральный университет \\ Россия, 660041, Красноярск, пр. Свободный, 79
}

\begin{abstract}
В статье проведен анализ промышленной политики, реализуемой в России в последние десятилетия. Сформулированы основные проблемы и перспективы реализации промышленной политики, включая возможности локализации деятельности крупных компаний. Проведен анализ особенностей промышленного развития Красноярского края. Сформулированы принципы промышленной политики, обеспечивающей развитие индустриального сектора в России, в регионах Сибири и Дальнего Востока. Рассмотрен комплекс задач, связанных с формированием промышленной политики региона с иелью выхода на инновационный путь развития и обеспечения роста высокотехнологичных секторов экономики, ориентированных на новые товарные рынки. Определены виды промышленной политики, их иели, задачи, особенности и потенциал. Разработаны предложения к промышленной политике Красноярского края.
\end{abstract}

Ключевые слова: промышленное производство в России, индустриальное развитие, промышленная политика, региональное развитие, промышленная политика Красноярского края.

Научная спещиальность: 08.00.00 - экономические науки. 